\title{
TRAUMATIC PARAPLEGIA IN ZARIA, NIGERIA: THE CASE FOR A CENTRE FOR INJURIES OF THE SPINE
}

\author{
By C. G. Iwegru, M.D., M.Ch.Orth, F.R.C.S.(Ed.), F.R.C.S.(Glasg.) \\ Lecturer and Consultant in Orthopaedic and Accident Surgery, Ahmadu Bello \\ University, Zaria, Nigeria.
}

Summary. This is a review of 48 patients with traumatic paraplegia treated at the Ahmadu Bello University Teaching Hospital, Zaria, Nigeria in the period June I973 to June I982. The records are unfortunately incomplete. All but three of the patients were treated conservatively. The mean hospital stay was 3 months. Facilities for adequate management including rehabilitation were lacking. Twelve patients (25 per cent) died within Io weeks of admission, 30 developed bed sores and all had urinary tract infection beginning whilst in hospital. Wheelchairs could not be provided by the hospital for those who did not recover motor function and most of the patients could not afford to buy them. Most of the patients treated earlier in the series were lost to follow up. In the last 12 months of the period under review, I 5 patients were treated using much the same facilities as existed in previous years. There was no hospital mortality during this period, and although urinary tract infection could not be prevented, only two of the patients ( 13 per cent) developed bed sores. It is suggested that the establishment of a Centre for Injuries of the Spine, with the direct involvement of the Government through the Ministry of Social Welfare, in the management of these patients will definitely improve the overall results.

Key words: Traumatic paraplegia; 'Developing countries'; Spinal Centres.

\section{Introduction}

THE pioneering work of Guttmann, Holdsworth, Bedbrook and others elucidated the pathology of traumatic paraplegia and placed its management on a scientific footing. In particular, Guttmann set the standards with which the results of the treatment of the spinal injured all over the world are compared. Unlike the developed countries, the management of paraplegics in the developing countries is yet to receive the emphasis it deserves, mainly because of manpower and financial restraints, with the result that the prognosis in these patients is very poor at the present time. Since the number of paraplegics in some of these countries is on the increase if only because of an increasing incidence of road traffic accidents, efforts at taking care of them should be intensified. Reports indicate that such efforts are being made in some of the countries such as India (Masalawala, I975; Chahal, I975) but information about efforts in Africa is scanty.

This paper is a review of 48 patients with traumatic paraplegia, with a brief note on nine patients who had traumatic tetraplegia. They were treated at the Ahmadu Bello University Teaching Hospital, Zaria during the period June I973 to June I982. Its objectives are to highlight the problems of management contributing to poor results, and to make a case for the establishment of a Centre for Injuries of the Spine (CIS) in Zaria. 
TABLE I

Age groups and sex of patients

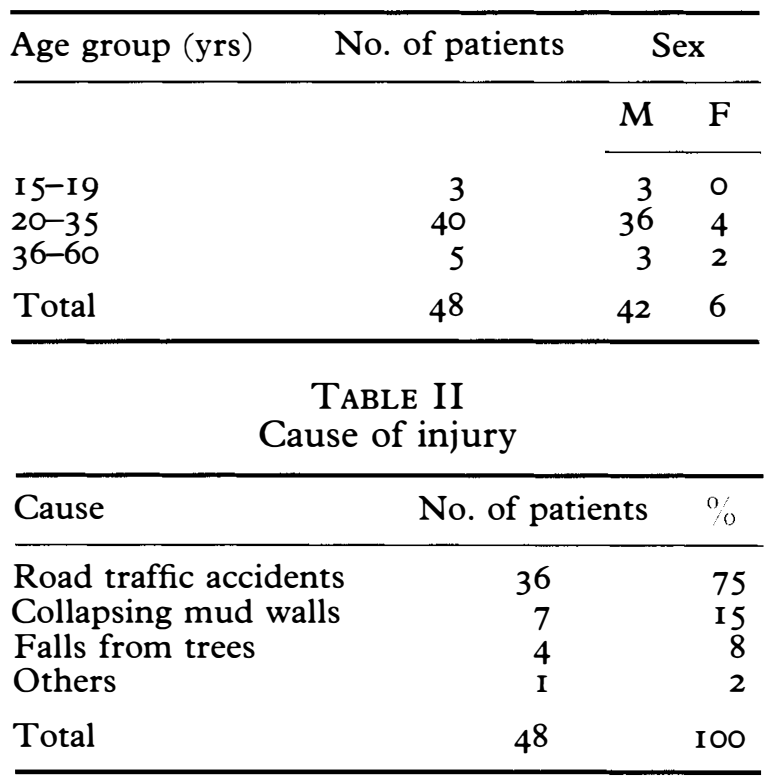

Analysis of the patients

Sixty seven patients, 60 males and 7 women, with traumatic tetraplegia and paraplegia were seen in the Casualty Department in the period under review. This figure does not include patients seen in 1980 whose records were not available, and those not admitted because of lack of beds or facilities. Fifty seven patients are the subject of this review. The records were incomplete for two paraplegic patients. Of the 48 paraplegic patients, 42 were males and 6 were females. The age range was is to 60 years with a mean age of 25 years (Table I). The neurological deficit was complete in 42 patients ( 88 per cent) and incomplete in 6 ( 12 per cent). The major causes of injury were road traffic accidents, collapsing mud walls and falls from trees (Table II). The interval between injury and attendance at Casualty ranged from 2 hours to 3 months. The patients were brought by buses, taxis and other vehicles. There was no form of splintage during transportation.

Most of the patients (94 per cent) were managed conservatively. In this respect there were two treatment periods-before I98I and after I98I. In the first period, treatment consisted of nursing on a 'hard' bed, by which was meant that a wooden board was placed under the bed springs. Postural reduction was not attempted. An urethral catheter was inserted on admission and left in situ and bladder training was not practised. Skin care was limited to the pressure areas; routine turning of patients was not carried out.

The complications of bed sores, urinary tract infection and chest infection were treated as they arose. Physiotherapeutic and other rehabilitative measures were carried out but not systematically. In the second 
period during which I 5 patients were treated for periods of not less than 4 months, postural reduction of fractures was attempted in all of the patients, using rolled pillows placed across a hard bed at the level of the fracture. Although proper bladder management could not be instituted because of lack of facilities, turning of the patients was carried out as routinely as staffing limitations permitted. Active efforts were made to prevent the common complications of management. Efforts at rehabilitation of the patients were made. In particular, they were taught to use a wheelchair.

Three patients with partial lesions and progressing neurological deficit underwent laminectomy.

Most of the patients were discharged home to their relatives but a number took their own discharge against medical advice.

\section{Results}

The hospital mortality of the 48 patients was 25 per cent and occurred within IO weeks of admission to hospital in the period to June I98I. All the six patients with partial lesions made some neurological recoverythree fully, including one patient who underwent laminectomy, and three partially, including two other patients who had a laminectomy. Attempted postural reduction could not be monitored effectively because of lack of adequate facilities.

Of the common complications, only bed sores and urinary tract infection were consistently recorded. Thirty patients (62 per cent) had the former and all of the patients (IOO per cent) had the latter complication. Some of the bed sores were extensive and deep and generally responded badly to treatment. Ten of the $\mathrm{I} 2$ patients who died had bed sores at the time of death. In the second treatment period, 2 of the 15 patients had superficial bed sores which responded well to treatment. Urinary tract infection was as common as in the first period but neither chest infection nor joint contractures were encountered. The upper limb and upper trunk muscles were reasonably well rehabilitated.

There was virtually no follow up in the first period. It remained poor in the second.

\section{Discussion}

Most of the patients were men in the age group 20-35 years. This agrees with most published series. The aetiological factors (road traffic accidents (75 per cent), collapsing mud walls ( 5 per cent) and falls from trees (8 per cent) reflect the realities of life in a developing country. Nigeria's annual motor vehicle import bill runs into several million Naira (I Naira $=0.8$ Pound Sterling). The roads are generally bad and the standard of driving is generally poor. On the other hand, a sizeable part of the rural population still live in mud houses and agriculture is largely unmechanised.

All of the six patients with partial neurological deficit had a significant recovery. As the patients were not brought to the hospital by trained personnel, it is possible that some of the complete lesions were initially incomplete and were rendered complete by uninformed handling at the site of accident and/or during transportation to hospital. The bed sore and 
urinary tract infection rates were very high. Significantly, the high hospital mortality was related to the decubitus sores (Table III). It is probable that the incidence of bed sores could have been less if adequate measures were taken. This is indicated by the results in the last 12 months of the review period in which only 2 of the I 5 patients developed bed sores. With regard to urinary tract infections, little could be done to prevent them because intermittent catheterization could not be instituted because of lack of facilities. Even indwelling catheters were in very short supply.

TABLE III

Cause of death in 12 patients

\begin{tabular}{lcc}
\hline Cause of death & No. of patients & No. with bed sores \\
\hline Toxaemia and Cachexia & 6 & 6 \\
Septicaemia & 2 & 2 \\
Not stated & 4 & 2 \\
Total & I2 & IO \\
\hline
\end{tabular}

\section{Comment on the Tetraplegic Patients}

During the period under review, nine tetraplegic patients were also seen. Seven resulted from road traffic accidents, one from a fall from a tree, and one from a fall when playing with a friend. Three patients were not admitted for lack of beds or facilities. Of the six admitted, one survived and was discharged home, two died within two weeks from respiratory failure, one died in the 5 th week after a posterior cervical fusion procedure, one died from toxaemia from bed sores and one was taken home by relatives. The last two patients were treated in the last 12 months of the review period. In summary, the outlook for those with traumatic tetraplegia was nearly hopeless.

Details of the other complications of treatment such as chest infection, muscle wasting, joint contractures and mental depression were not recorded but it is probable that they occurred in some if not most of the patients. With the high rate of complications, poor rehabilitation and virtually nonexistent social services, a bad prognosis in these patients was and remains inevitable.

\section{Conclusions}

The position of paraplegics in the developing countries today is comparable to that which existed in Europe in pre-Guttmann times. There is no doubt that the prognosis can be improved if proper facilities are provided and if the teachings of Guttmann and his associates are popularised and practised. For example, in spite of insufficient national resources, some paraplegics in India now stand a chance of rehabilitation and gainful postinjury existence (Masalawala, 1975). Nigeria, though industrially less developed than India, is a potentially rich country both in monetary and manpower terms. She can set the pace for the rest of black Africa by establishing Centres for Injuries of the Spine (CIS) which will take care of her many paraplegics who have over the years cried in vain for help. She can tackle the problem further by establishing homes or hostels to care for those paraplegics who after discharge from hospital do not 
have suitable homes to go back to. Through the Ministry of Social Development, efforts can be made to improve the home conditions of those paraplegics who prefer to live at home with their relatives. This muchneeded experiment can be started at Zaria which has a sizeable population of these patients as well as the basic infra-structure required for the establishment of a Spinal Centre, the benefits of which will spill over to other patients with other spinal diseases.

\section{RÉSUMÉ}

Paraplégie traumatique à Zaria au Nigéria. Cas exigeant l'établissement d'un Centres des Blessures de l'Epine Dorsale.

Le Résumé

Il s'agit ici d'une revue de 48 patients atteints de la paraplégie traumatique dont le traitement a eu lieu a l'Ahmadu Bello University Teaching Hospital, Zaria, Nigéria à partir du mois de juin, I973 jusqu'au mois de juin, I982. Les documents sont incomplets et les quadruplégiques sont exclus. Tous les patients, à l'exception de trois, étaint soignés de façon conservatrice. Le séjour moyen a l'hôpital était trois mois. On constate un marque général de facilités nécessaires pour la gestion et la rehabilitation adéquates. Douze patients $(25 \%)$ sonts morts au cours de dix semaines d'admission, trente d'eux $(62 \%)$ sont développé les escarres et tous étaient en proie à l'infection du tract urinaire lors de leur sejour a l'hôpital. L'hôpital ne pouvait pas procurer à ceux qui ont perdu la fonction motrice les voitures de malade et la plupart de patients se montraient incapables de les acheter. En fait, tous les patients traités prealablement dans la serie ne se luraient pas suivre de pres. Pendant les douze derniers mois de l'époque en question, on s'est servi de virtuellement les mêmes facilités qu'aux années écoulées pour traiter Is patients. Aucune mortalite hopitalière n'a ete relevée à cette période-ci, et bien que l'infection du tract urinaire ne puisse être empêchee, il n'y avait que deux patients (13\%) qui ont développé les escarres. Il est proposé que les resultats globaux s'amélioreront évidemment grâce à l'établissement d'une Centre des Blessures de l'Epine Dorsale et la participation directe du gouvernement aux soins de ces patients par l'intermédiare du Ministere de l'Assistance Sociale.

\section{ZUSAMMENFASSUNG}

Dies ist eine Untersuchung an 48 Patienten mit traumatischer Paraplegie, die im Zeitraum Juni 1973 bis Juni 1982 in der Universitätsklinik der Ahmadu Bello Universität, Zaria, Nigeria, behandelt wurden. Die Krankengeschichten sind unvollständig, und Patienten mit traumatischer Quadriplegie wurden von der Untersuchung ausgeschlossen. Außer 3 Patienten wurden alle übrigen konservativ behandelt. Der durchschnittliche Krankenhausaufenthalt betrug 3 Monate. Im allgemeinen standen Mittel zur fachgerechten Behandlung und Rehabilitierung nicht zur Verfügung. 12 Patienten $(25 \%)$ verstarben innerhalb der ersten Io Wochen nach Aufnahme, $30(62 \%)$ entwickelten Durchlagegeschwüre und alle hatten Harnweginfekte während des Aufenthalts. Für diejenigen, die keine motorischen Funktionen wieder entwickelten, konnten vom Krankenhaus keine Rollstühle zur Verfügung gestellt werden, und die meisten Patienten verfügen nicht über die erforderlichen finanziellen Mittel, um sich solche zu kaufen. Nachuntersuchungen waren praktisch für alle Patienten, die in den ersten Jahren der Untersuchung behandelt wurden, unmöglich. I5 Patienten wurden während der letzten I 2 Monate des angegebenen Untersuchungszeitraums praktisch in der selben Weise wie in den vorangegangenen Jahren behandelt. Keiner dieser Patienten verstarb während des Klinikaufenthaltes, und obwohl Harnweginfekte nicht verhindert werden konnten, entwickelten nur 2 Patienten (13\%) Durchlagegeschwüre. Es wird der Vorschlag gemacht, ein Zentrum für Wirbelsäulenverletzungen einzurichten und die Regierung direkt über das Sozialministerium in die Behandlung solcher Patienten einzuschalten. Auf diese Weise würde die Erfolgsquote der Behandlung bedeutend ansteigen.

\section{REFERENCES}

Chahal, A. S. (I975). Care of spinal cord injuries in the Armed Forces of India. Paraplegia, 13, 25-28.

Masalawala, K. S. (1975). Experiences with traumatic paraplegic patients in India. Paraplegia, 13, 29-35. 